\section{Dampak pemantauan sejawat terhadap biaya kafalah: pendekatan eksperimen}

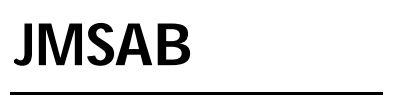

\section{Agus Munandar}

Fakultas Bisnis, Institut Teknologi dan Bisnis Kalbis, Jakarta, Indonesia

\begin{abstract}
This study aims to examines impact of peer monitoring on cost of kafalah financing. Based on mixed results on severals recents studies and the significance of this issue to islamic banking costing, it is important to recognize the condition under context to reduce cost kafalah financing. This study employes experimental method for confirming hypothesis. This study provides evidence that peer monitoring reduces cost of nonrepayment in kafalah financing. This findings give implication for banks management when provides kafalah financing.
\end{abstract}

\section{Abstrak}

Studi ini bertujuan untuk menguji dampak pemantauan sejawat terhadap biaya pembiayaan kafalah. Berdasarkan hasil penelitian sebelumnya yang beragam dan pentingnya isu biaya kafalah atas perbankan, penelitian ini bermaksud mengidentifikasi konteks untuk menurunkan biaya pembiayaan kafalah. Penelitian ini menggunakan metode eksperimen untuk mengkonfirmasi hipotesis penelitian. Hasil penelitian memberikan bukti bahwa pemantauan sejawat menurunkan biaya pembiayaan kafalah. Hasil penelitian ini bermakna untuk manajemen bank ketika menyalurkan pembiayaan kafalah.

Email korespondensi: agus.munandar@kalbis.ac.id

Pedoman Sitasi: Agus Munandar (2018). Dampak pemantauan sejawat terhadap biaya kafalah: pendekatan eskperimen. Jurnal Manajemen Strategi dan Aplikasi Bisnis, 1(1),1 - 8
Paper type Research paper

Keywords: Peer monitoring, Experiment, Cost managerial

Received: 20 September 2018

Accepted: 16 November 2018

Online: 31 December 2018

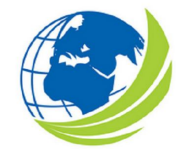

Jurnal Manajemen Strategi dan Aplikasi Bisnis, Vol 1, No.1, Desember 2018, pp.1 - 8

eISSN 2655-237X 


\section{PENDAHULUAN}

Berbagai studi telah memberikan bukti empiris bahwasanya pembiayaan kafalah (kafalah loan) memiliki keunggulan yaitu mengurangi moral hazard, mengurangi kredit macet, dan meningkatkan kepatuhan pembayaran. Pembiayaan kafalah telah jamak dimanfaatkan oleh masyarakat di negara berkembang karena keterbatasan jaminan (kolateral). Untuk itu, pendanaan kafalah memberikan kesempatan akses keuangan oleh masyarakat.

Di sisi lain, pembiayaan kafalah sangat rentan terhadap biaya piutang tak tertagih (non performing loan/ NPL). Di indonesia, isu piutang tak tertagih merupakan masalah utama. Berdasarkan data statistik yang diterbitkan oleh Bank Indonesia, NPL mengalami peningkatan sejak 2013 yang ditunjukkan pada Grafik sebagai berikut:

\section{Grafik 1. NPL (Non Performing Loan) Tahun 2013-2017}

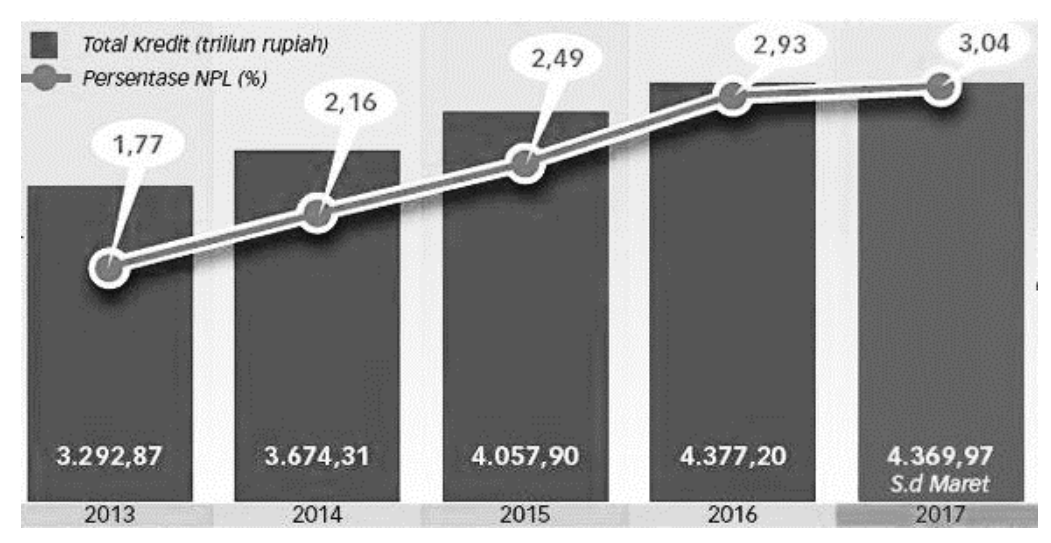

Sumber: Bank Indonesia

Pembiayaan kafalah merupakan model pembiayaan alternatif untuk mengatasi piutang tak tertagih (cost of non repayment). Berdasarkan penelitian sebelumnya, pembiayaan kafalah mampu mengurangi biaya piutang tak tertagih sebesar 80-95\% (Puhazhendi \& Badatya, 2002; Chauhan \& Verma, 2001). Untuk itu, hasil penelitian tersebut memberikan temuan bahwa pembiayaan kafalah dapat mengurangi biaya piutang tak tertagih. Riset eksperimen pembiayaan kafalah di lima negara: India, Kenya, Guatemala, Armenia, dan Filipina menunjukkan bahwa pembiayaan kafalah secara positif dan signifikan mempengaruhi tingkat pembayaran kembali atau pelunasan pinjaman (Cassar \&Widdyick, 2010).

Rendahnya biaya atas piutang tak tertagih karena pembiayaan kafalah menuntut kepada setiap anggota kelompok untuk bertanggungjawab atas pinjaman kelompoknya. Untuk itu, pada saat salah satu anggota kelompok tidak mampu mengembalikan pinjaman maka pelunasannya ditanggung bersama. Keberadaan modal sosial ini dapat menjadi pengganti atau penguran agunan fisik (Wydick, 1999).

Walaupun demikian, berbagai studi empiris sebelumnya juga menunjukan bahwa pembiayaan kafalah tidak dapat meningkatkan pelunasan pinjaman (Attanasio et al., 2015). Berdasarkan keragaman dan ketidakkonsistensian temuan penelitian sebelumnya dan pentingnya isu ini terkait biaya manajerial, maka penting untuk memahami kondisi atau konteks pembiayaan kafalah agar dapat meningkatkan pelunasan dan mengurangi biaya piutang tak tertagih. Untuk itu, penelitian ini bermaksud untuk menyelidiki konteksi yang dapat mengurangi biaya piutang tak tertagih, yaitu pemantauan sejawat.

Penelitian ini berfokus pada pemantauan rekan (Stiglitz, 1990); Banerjee et al., 1994). Konteks ini sangat penting dalam sistem pengendalian manajemen. Pertama, ada kemungkinan bahwa kinerja tingkat pembayaran tergantung pada bervariasi pada pemantauan rekan. Selain itu, sebagian besar 
topik manajerial sangat berkaitan dengan pemantauan (monitoring). Ketiga, terdapat kemungkinan bahwa biaya piutang tak tertagih tergantung pada tingkat pemantauan rekan.

Dalam konteks Indonesia, studi empiris dalam pembiayaan kafalah masih jarang. Berdasarkan pendekatan kontingensi bahwa tidak ada sistem yang tepat untuk segala konteks, maka riset ini perlu dilakukan di Indonesia. Berdasarkan data dari DBS Bank (2017), Indonesia merupakan populasi bankable terendah di dunia. Akhirnya, riset empiris mengenai pembiayaan kafalah sangat penting dalam konteks Indonesia.

Studi ini memiliki alur pemaparan sebagai berikut. Pertama, membahas teori dan hipotesis mengenai bagaimana pemantauan rekan mempengaruhi hubungan pembiayaan kafalah terhadap biaya piutang tak tertagih. Kedua, membahas metode untuk melakukan eksperimen. Ketiga, membahas hasil penelitian ini. Di bagian akhir, ini memberikan kesimpulan.

\section{KAJIAN PUSTAKA}

Teori Perilaku Yang Direncanakan (Theory of Planned Behaviour)

Berdasarkan teori perilaku yang direncanakan (TPB), Ajzen (2006) menunjukkan bahwa perilaku manusia dipengaruhi oleh tiga pertimbangan seperti keyakinan perilaku, keyakinan normatif dan keyakinan kontrol. Teori relevan untuk menggambarkan pembayaran pembiayaan kafalah. Hal ini menjelaskan bahwa seseorang yang bersepakat bergabung dalam kelompok pembiayaan kafalah telah memiliki keyakinan perilaku yang menggambarkan tentang pertimbangan tentang hasil perbuatan, adapun keyakinan normatif percaya tentang harapan orang lain (anggota atau kelompok), dan keyakinan kontrol menggambarkan tentang faktor-faktor yang dapat mempengaruhi kinerja perilaku. Berdasarkan teori perilaku yang direncanakan (TPB), Francis et al (2004) menjelaskan bahwasanya niat dan perilaku perilaku sikap anggota ditentukan oleh perilaku, norma subyektif, dan perilaku yang dirasakan (ditunjukkan pada Gambar.1).

Teori perilaku yang direncanakan (TPB) dapat digunakan untuk mengidentifikasi perilaku peminjam (Makorere, 2014). Secara umum, berbagai penelitian ini telah mengidentifikasi bahwa proses pembayaran pinjaman adalah fungsi dari perilaku peminjam, karakteristik bisnis, karakteristik lembaga keuangan dan kebijakan serta masalah regulasi. Walaupun demikian, penelitian ini secara spesifik mengidentifikasi konteksi yang dapat mengurangi biaya piutang tak tertagih, yaitu pemantauan sejawat.

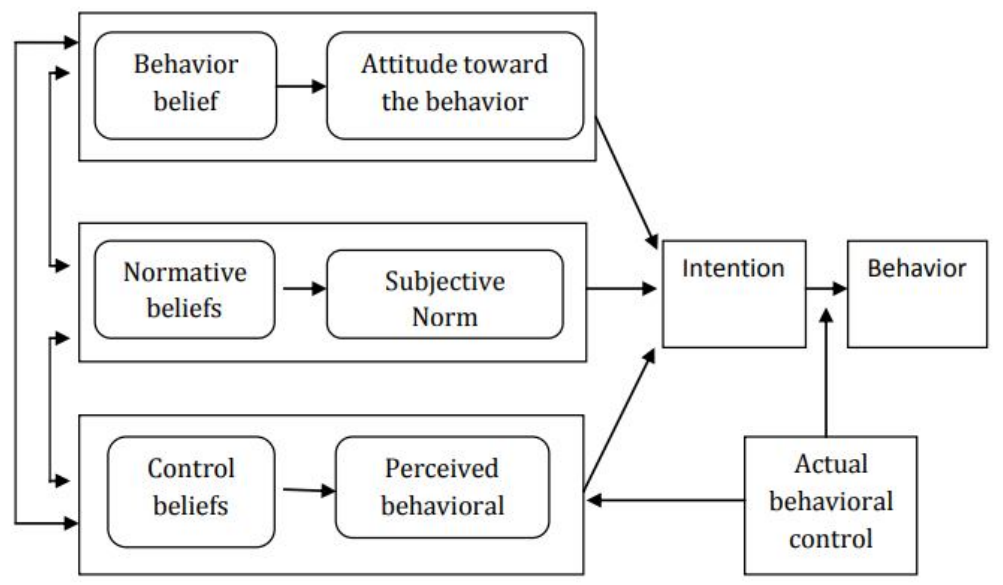

Gambar 1. Model Perilaku Terencana The Planned Behavioral Model

Sumber: Francis et al., 2004 
Tipe Pemantauan Rekan (Type Of Peer Monitoring)

Tipe Pemantauan Rekan (Peer monitoring ) terdiri dari dua jenis, (1) pemantauan rekan tidak langsung, hal ini terjadi ketika para debitur melakukan gosip atas rekan-rekan yang tidak melunasi pinjamannya, dan (2) pemantauan rekan langsung, hal ini terjadi pada saat peminjam mengoreksi dan menegur anggota tim yang tidak menunaikan kewajibannya. Oleh karena itu, praktik tipe pemantauan rekan terjadi pada saat anggota grup memperhatikan dan menanggapi perilaku atau kinerja rekan mereka. Sehingga, tipe pemantauan rekan memiliki asosiasi negative terhadap biaya piutang tak tertagih (cost of non repayment).

Kafalah

Dewan Penasihat Syariah Bank Negara Malaysia (Shariah Advisory Council of Bank Negara Malaysia), kafalah didefinisikan sebagai kontrak jaminan yang diberikan oleh penjamin kepada pihak-pihak yang terlibat dalam aset atau pinjaman tertentu. AAOIFI (2010) Standar Syariah No. 23 mendefinisikan kafalah sebagai "tindakan satu pihak yang mendelegasikan yang lain untuk bertindak atas namanya pada apa yang dapat menjadi subyek delegasi."

Kafalah didefinisikan sebagai adalah bentuk jaminan oleh semua anggota dalam kelompok untuk pinjaman bagi kelompok tersebut yang harus dibayar kembali pada waktunya dan sesuai dengan hukum Islam. Untuk itu, kafalah didefinisikan seperti di bawah ini:

"Menyatukan tanggung jawab penjamin kepada tanggung jawab orang yang dijamin dalam komitmen untuk menunaikan hak wajib, baik diwaktu itu atau dimasa yang akan datang" ( AlFiqhu al-muyassar, 6/ 106).

Hubungan Peer Monitoring dan Biaya Kafalah

Sebagaimana dinyatakan oleh Stiglitz (1990), Banerjee et al. (1994), dan Wydick (2001), bahwa pemantauan rekan dalam pembiayaan kafalah dapat membantu mengurangi moral hazard. Selain itu, Cassar \& wydick (2010) juga telah melakukan studi empiris dan menemukan bahwa pemantauan rekan adalah alat yang efektif di Guatemala dan Filipina. Untuk itu, tipe pemantauan rekan antar anggota kelompok dapat mengurangi moral hazard dan biaya piutang tak tertagih (cost of non repayment).

Penelitian lainnya menjelaskan bahwa Sekitar 80-95 persen tingkat pelunasan dapat terjadi karena tingkat pemantauan rekan yang tinggi (Chauhan \& Verma, 2001; Puhazhendi \& Badatya, 2002). Beberapa penelitian juga memberikan bukti empiris bahwa, pemantauan rekan memiliki pengaruh negatif pada biaya piutang tak tertagih (Feroze et al., 2011; Kritikos \& Vigenina, 2005).

Berdasarkan pemaparan di atas, hipotesis yang diajukan pada penelitian ini menjelaskan hubungan tipe pemantauan rekan yang berinteraksi dengan pinjaman kelompok sehingga mempengaruhi biaya piutang tak tertagih atau tingkat pembayaran kembali. Berdasarkan teori pemantauan rekan, setiap anggota kelompok memiliki insentif untuk mengendalikan rekannya sehingga setiap anggota kelompok berusaha untuk melunasi pinjamannya. Untuk itu, hipotesis dapat dinyatakan sebagaimana berikut:

Hipotesis: Peer monitoring mengurangi biaya kafalah piutang tak tertagih.

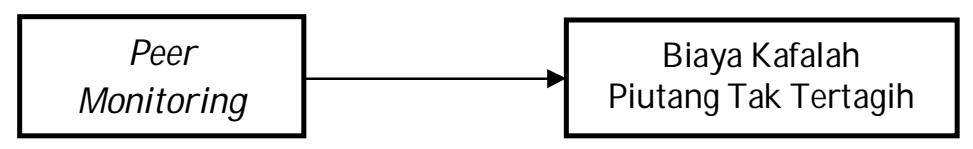

\section{Gambar 2. Kerangka Model Penelitian}


Jurnal Manajemen Strategi dan Aplikasi Bisnis, 1(1), 1-8

Munandar, A., dampak pemantauan sejawat terhadap biaya kafalah

\section{METODE PENELITIAN}

Desain Penelitian

Eksperimen ini dilakukan di kelas (laboratory experiment). Rancangan penelitian eksperimental ini adalah pre-test, post-test control group design dalam subjek, dengan satu manipulasi yaitu pemantauan rekan. Instrumen eksperimen yang digunakan dalam rancangan pre-test post-test control group design adalah permainan pembiayaan kafalah yang dikembangkan oleh Cassar dan Widyck (2010) dengan beberapa modifikasi dan penyesuaian untuk konteks Indonesia.

Populasi dan Sampel

Berdasarkan rekomendasi Cowles dalam Christensen (1988) bahwa jumlah minimal peserta (ukuran sampel) untuk setiap kelompok eksperimen adalah 15 subjek. Untuk itu, jumlah peserta yang terlibat dalam eksperimen ini adalah 15 dalam subjek.

Subjek untuk penelitian ini adalah mahasiswa praktisi (sudah bekerja) di Kalbis Institute. Menggunakan mahasiswa sebagai penyulih manajer professional diperbolehkan sebagaimana argumentasi Liyanarachchi \& Milne (2005). Argumen ini konsisten dengan Nahartyo (2012) yang menunjukkan bahwa mayoritas penelitian perilaku hanya berfokus pada bagaimana individu memproses informasi dan membuat keputusan secara umum sehingga mahasiswa valid untuk penelitian eksperimen sejenis. Selain itu, tugas-tugas eksperimental dalam penelitian ini sederhana sehingga mahasiswa tetap sahih untuk penelitian ini.

Pengukuran Variabel

Variabel dependen dalam penelitian ini adalah biaya piutang tak tertagih. Variabel ini dihitung menggunakan rasio kartu keputusan tidak berkontribusi dibagi total anggota. Misalnya, jika suatu kelompok memiliki enam peminjam dan terdapat dua orang yang tidak berkontribusi, biaya piutang tak tertagih (cost of non repayment) menjadi 2 anggota / 6 anggota $=0,33$ atau 33\%. Serta Variabel Independen dalam penelitian ini adalah pemantauan sejawat (peer monitoring).

Teknik Analisis

Teknik analisis yang digunakan menggunakan pendekatan eksperimen serta untuk menguji hipotesa penelitian dengan teknik analisis Uji Beda. Menurut Cassar dan Wydick (2010), Eksperimen menggunakan jenis permainan karena tiga pertimbangan penting yaitu: (1) struktur permainan mempertimbangkan informasi pribadi; kerugian investasi adalah informasi anggota. (2) dapat mengidentifikasi moral hazard, dan (3) menggabungkan insentif dinamis, anggota kelompok cenderung membayar kembali pinjaman kelompok untuk mengakses pinjaman peluang di masa depan.

Eksperimen dimulai dengan menjelaskan dengan lugas tentang instruksi permainan, dan menjawab beberapa pertanyaan dari partisipan, dan memberikan satu uji coba, dan mengajukan beberapa pertanyaan untuk memastikan pemahaman mereka. Alur kerja atau proses untuk melakukan pre-test post-test control group design penelitian eksperimental ini dapat digambarkan sebagai berikut: 


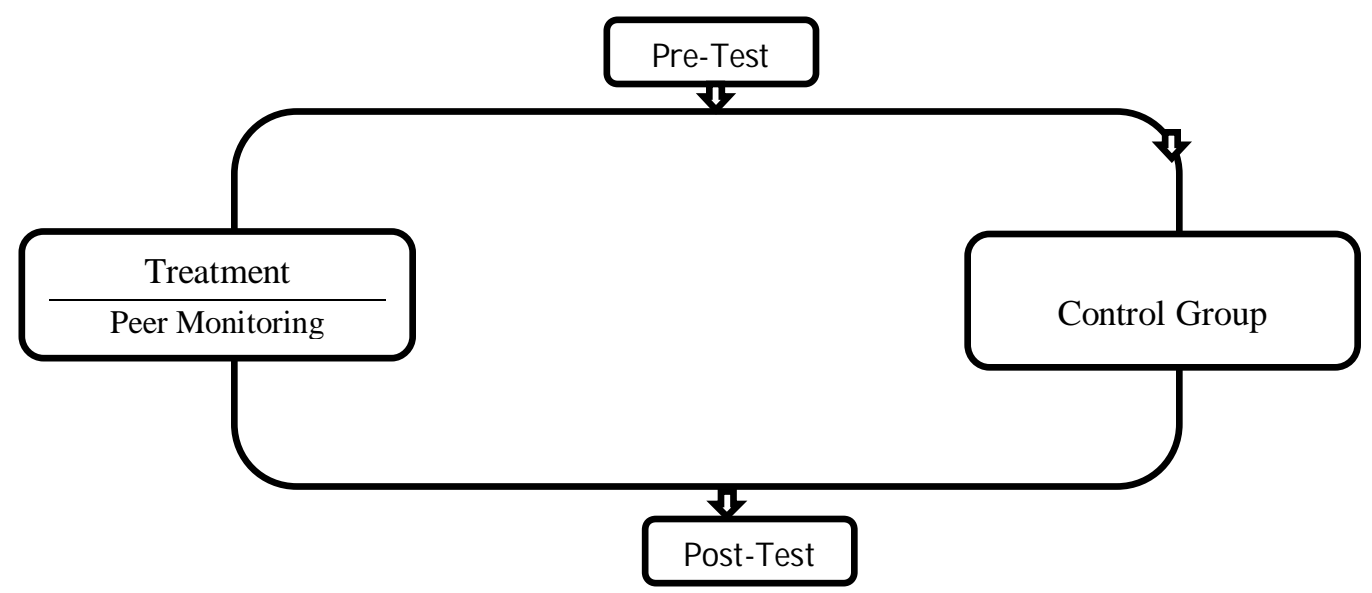

Gambar 3. Alur pre-test post-test control group design

\section{HASIL DAN PEMBAHASAN}

\section{Statistik Deskriptif}

Tabel 1 menyajikan statistik deskriptif untuk karakteristik partisipan berdasarkan keengganan partisipan dalam kontribusi pembiayaan kafalah. Berdasarkan statistik deskriptif diketahui bahwa nilai rata-rata kelompok kontrol adalah 0,688 dan untuk peer monitoring adalah 0,322.

Berdasarkan tabel deskriptif, dapat disimpulkan bahwa konteks pembiayaan kafalah, kelompok peer monitoring berbeda dari kelompok kontrol. Untuk itu, konteks peer monitoring sangat penting untuk mengembangkan kebijakan pinjaman tanggung jawab bersama. Hal ini berdasarkan skor rata-rata yang menurun dari 0,688 (kontrol) menjadi 0,3222 (Peer monitoring). Kesimpulannya, konteks peer monitoring merupakan mekanisme yang efisien untuk mengurangi biaya piutang tak tertagih.

Tabel 1. Statistik Deskriptif

\begin{tabular}{lllccc}
\hline & & Value Label & $\mathrm{N}$ & $\mathrm{Mean}$ & Std. Deviation \\
\hline Treatment & 0 & Control & 15 & .6889 & .18758 \\
& 1 & Peer monitoring & 15 & .3222 & .13313 \\
\hline
\end{tabular}

Sumber: data diolah

Uji Hipotesis

Tabel 2 menyajikan hasil analisis uji beda yang memberikan informasi efek utama variabel perlakuan. Berdasarkan hasil pengujian statistik, konteks pembiayaan kafalah (Peer monitoring) memiliki dampak signifikan pada biaya pitang tak tertagih ( Sig. <0, 05). Hal ini konsisten dengan statistik desriptif yang menunjukkan nilai rata-rata menurun dari 0,688 (kontrol) menjadi 0,3222 (Peer monitoring). Untuk itu, dapat disimpulkan bahwa konteks peer monitoring adalah alat yang efisien untuk mengurangi biaya tidak membayar kembali. Akhirnya, konteks adalah faktor penting untuk mengurangi biaya pembayaran kembali.

Temuan ini sejalan dengan rerangka teoritis sebelumnya pada pembiayaan kafalah (Stiglitz, 1990; Banerjee et al., 1994) yang menyarankan bahwa pemantauan rekan dan informasi asimetris yang rendah dapat mempermudah arus informasi yang tinggi antar anggota. Hal ini mengarah pada modal sosial yang menjadi peran penting dalam mengurangi pinjaman non-pembayaran. Untuk itu, menerima hipotesis yang diajukan. 
Jurnal Manajemen Strategi dan Aplikasi Bisnis, 1(1), 1-8

Munandar, A., dampak pemantauan sejawat terhadap biaya kafalah

\section{Table 2. Hasil Pengujian (Comparison Result)}

(I) Treatment $\quad$ (J) Treatment $\quad$ Mean Difference (I-J) Std. Error $\quad$ Sig.

\begin{tabular}{|c|c|}
\hline Control & \\
\hline
\end{tabular}

Sumber: data diolah

\section{KESIMPULAN}

Kesimpulan

Penelitian perilaku menunjukkan bahwa perilaku manusia dimotivasi oleh keyakinan perilaku, keyakinan normatif, dan keyakinan kontrol. Penelitian ini meneliti efek peer monitoring terhadap biaya piutang tak tertagih di pembiayaan kafalah. Hasil penelitian menunjukkan bahwa kemampuan anggota kelompok untuk memantau anggota lain dalam satu kelompok pembiayaan kafalah menghasilkan efek positif pada tingkat pembayaran kembali pinjaman. Untuk itu, pemantauan ini mengurangi informasi asimetris dalam kelompok dan mendorong kinerja pembayaran kembali. Akhirnya, kesimpulan dari penelitian ini bahwa peer monitoring meruapakan mekanisme yang dapat mengurangi biaya pembayaran kembali.

Implikasi Praktis / Teoritis

Temuan ini memiliki implikasi bahwa konteks mekanisme, pemantauan rekan, penting dalam pembiayaan kafalah. Hal ini memiliki implikasi yang signifikan untuk mengembangkan kebijakan keuangan inklusif terutama untuk penduduk yang tidak memiliki agunan finansial. Sebagaimana diketahui bahwa inklusi keuangan adalah penting karena memberikan kesempatan kepada individu dan bisnis untuk mengakses produk keuangan yang terjangkau untuk kebutuhan mereka seperti pembayaran, kredit, transaksi, dan asuransi. Dengan demikian, bukti ini menunjukkan bahwa regulator hendaknya mempertimbangkan konteks ketika mengembangkan kebijakan pembiayaan kafalah. Akhirnya, temuan ini memberikan kontribusi yang signifikan untuk pengembangan kebijakan pembiayaan kafalah.

Keterbasan dan Saran

Desain eksperimen dalam penelitian ini memiliki keterbatasan terkait peserta eksperimen. Subyek dalam penelitian ini adalah mahasiswa pekerja. Para peserta merupakan pemula dalam pembiayaan kafalah dan mereka tidak memiliki pengalaman meminjam. Dengan demikian, hasil penelitian ini tidak dapat digeneralisasi ke peminjam praktisi. Namun, temuan eksperimen ini dapat menangkap dampak konteks pada biaya piutang tak tertagih di konteks pembiayaan kafalah. Sehingga untuk penelitian berikutnya dapat menambah jumlah cakupan sampel dan objek penelitian.

\section{REFERENSI}

Ajzen, I. (1991), The theory of planned behavior, Organization Behaviour and Human Decision Processes, Vol. 50 No. 3, pp.179-211.

Attanasio, O., B. Augsburg, R. De Haas, E. Fitzsimons, and H. Harmgart (2015) "The Impacts of Microfinance: Evidence from Joint-Liability Lending in Mongolia," American Economic Journal: Applied Economics, 7, 90-122.

Banerjee, A., Besley, T., and Guinnane, T. (1994) Thy neighbor's keeper: design of a credit cooperative with theory and a test, Quarterly Journal of Economics, 102, 491-515.

Besley, T. and Coate, S. (1995) Group lending, repayment incentives and social collateral, Journal of Development Economics, 46, 1-18. 
Jurnal Manajemen Strategi dan Aplikasi Bisnis, 1(1), 1-8

Munandar, A., dampak pemantauan sejawat terhadap biaya kafalah

Cassar, A., Wydick, B. (2010). Does Social Capital Matter? Evidence from a Five-Country Group Lending Experiment. Oxford Economic Papers 62 (2010), 715-739

Chauhan, A.K. and Verma, N.K. (2001) Comparative performance of major micro financing agencies for dairying in Haryana. Indian Journal of Agricultural Economics, 56 (3):474-75.

Cristensen, L.B. (1988). Experimental Methodology. 4th Edition. Allyn and Bacon, Inc.

DBS Bank (2017). Indonesian Multi-Finance Companies - DBS Bank

Feroze, S. M., Chauhan, A. K., Malhotra, R., \& Kadian, K. S. (2011). Factors Influencing Group Repayment Performance in Haryana: Application of Tobit Model. Agricultural Economics Research Review, 24(1).

Francis, J., Malhotra, K.O. and Mayoux, T. (2004), Constructing questionnaires based on the theory of planned behaviour, A manual for health services researchers, Centre for health services research, University of Newcastle, United Kingdom.

Kinney W.R., (1986). Empirical Accounting Research Design for Ph.D. Students. The Accounting Review (April, 1986), pp. 338-350.

Kritikos, A. S., \& Vigenina, D. (2005). Key Factors of Joint-Liability Loan Contracts: An Empirical Analysis. Kyklos, 58(2), 213-238.

Liyanarachchi, Gregory \& Milne, Markus. (2005). Comparing the Investment Decisions of Accounting Practitioners and Students: An Empirical Study on the Adequacy of Student Surrogates. Accounting Forum. 29.121-135. 10.1016/j.accfor.2004.05.001.

Makorere, R. F. (2014). Factors affecting loan repayment behaviour in Tanzania: Empirical evidence from Dar es Salaam and Morogoro regions. International Journal of Development and Sustainability, 3(3), 481-492.

Nahartyo, Ertambang. 2012. Desain dan Impelementasi Riset Eksperimen. Yogyakarta: UPP STIM YKPN

Puhazhendi, V. and Badatya, K.C. (2002) SHG-Bank linkage programme " An impact assesment. In: Proceedings of the Seminar on SHG-Bank Linkage Programme, held at New Delhi, 25-26 November.

Stiglitz, J. (1990) Peer monitoring and credit markets, The World Bank Economic Review, 4, 351-66.

Wydick, B. (1999) Can social cohesion be harnessed to mitigate market failures? Evidence from group lending in Guatemala, Economic Journal, 109, 463-75.

Wydick, B. (2001) Group lending under dynamic incentives as a borrower discipline device, Review of Development Economics, 5, 406-20.

\section{Profil Penulis}

Agus Munandar adalah dosen Prodi Akuntansi Fakultas Bisnis, Institut Teknologi dan Bisnis Kalbis, Jakarta Indonesia. Alamat korespondensi: agus.munandar@kalbis.ac.id 